\section{Lithium Mineralization of the Idermeg zone in Central Mongolia: Petrography and Mineralogical study}

\section{KHASHBAT DASHTSEREN $^{1 *}$ BOLDBAYAR NARANBILEG $^{2}$} JARGALAN SEREENEN ${ }^{3}$ ANTONIO ARRIBAS ${ }^{3}$

${ }^{1}$ Mongolian University of Science and Technology (MUST), Ulaanbaatar 14191, Mongolia (khashbat.d@must.edu.mn)

${ }^{2}$ Golden Hill LLC, Ulaanbaatar 14182, Mongolia (boldbayar@goldenhill.mn)

${ }^{3}$ MUST, Ulaanbaatar 14191, Mongolia (jargalan@must.edu.mn)

${ }^{4}$ The University of Texas at El Paso, El Paso, TX 79968, USA (aarribas@utep.edu)

\section{Introduction}

The most important means of storing energy is the lithium battery and the capacitor, therefore the significance is high for conducting studies on the most important raw material of lithium battery and assessing its future prospect.

In Mongolia, lithium mineralization is usually found in the pegmatite, and the Idergmeg zone is an area of great interest.

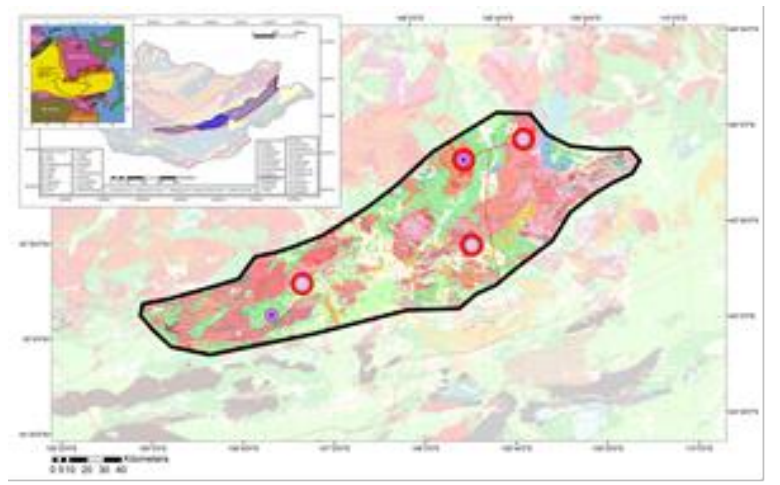

Figure 1. Location map of lithium deposits and occurrences in the Idermeg zone [Deposit: Munkhut (MTD), Occurrences: Khukhdel (KDO), Bayan Teeg (BTO) and New (NWO)]

Methods

Sample preparation, microscopic observation, chemical analysis (ICP, XRF), X-ray diffractometer (XRD) analysis, scanning electron microscope (SEM-EDX) analysis, and measurement Fluid Inclusion Thermobarometer analysis were accomplished within the framework of non-degree research program in the ICREMER, Akita University..

\section{Results and Discussion}

As a result of the study, petrographic and mineralogical characteristics of lithium deposit and occurrences was very similar. Lithium mineralization is related lithium bearing pegmatites named LCT (Lithium - (Cesium) - Tantalum) type pegmatite. Mineralization type classified two assemblages are lepidolite and quartz lepidolite.

Accessory minerals were revealed cassiterite, tantaniobite, apatite and zircon.

Lithium mineralization of the Idermeg zone developed by one system following from South West to North East directed regional structure.

\section{Acknowledgement}

I acknowledge all supports for this work was provided by Research Project of Mineral Resources for Renewable Energy Technologies (SHUUZ 2017/17) founded by Mongolian Foundation for Science and Technology and MongoliaJapanese Engineering Education Development Project (MJEED) MON P-11.

References

1. Černý, P. \& ercit, t.S. (2005), The classification of granitic pegmatites revisited. Canadian Mineralogist 43, p2005-2026.

2. Badarch G., Cunningham W.D., Windley B.B., (2002), A new terrane subdivision for Mongolia: implications for the Phanerozoic crustal growth of Central Asia, J. of Asian Earth Sciences 21, p87-110.

3. Jahn et al, (2004), Schematic map of the CentralAsian Orogenic belt showing the domains with predominantly.

4. Tomurtogoo O. (Editor-in chief), (1999). Geological Map of Mongolia, scale 1:1 000000 (with Brief Explanatory No.tes, 23 p.). Ulaanbaatar, Geological Information Center, p15.

6. U.S. Geological Survey, (2017), Mineral commodity summaries 2017: U.S. Geological Survey, p202 